\title{
Peer review or barbecue? The choice is clear
}

A $s$ a rule of thumb, new investments in research are usually applauded within Canadian scientific circles, particularly a sizeable amount such as the \$350 million earmarked for a newly minted federal program called the Centres of Excellence for Commercialization and Research. Yet, closer examination of Finance Minister Jim Flaherty's announcement about the program, part of the Mar. in federal budget, should cause the research community considerable consternation.

Two elements of the program, totalling \$245 million, are unassailable in that they are being allocated to projects that have or will meet international standards of excellence determined through peer review. This includes \$195 million for a competition to be held next year to establish an unspecified number of new Centres of Excellence and \$50 million for Waterloo's renowned Perimeter Institute for Theoretical Physics.

What of the remaining \$105 million? It is being distributed equally among 7 institutes, chosen by federal finance and industry bureaucrats and cabinet ministers without scientific due process (see page I406).

Each institute garnered a \$I5 million windfall without scientific input into the selection of areas in which such investments might be made, and without scientific peer review to determine whether the specific allocations were warranted, or whether other groups in the field were more suitable recipients. That is a dangerous precedent and a breach of the principles that underpin Canadian investments in academic research.

Officials argued that the move was not unprecedented, given that large investments have previously been made in specific institutes, such as the Perimeter Institute for Theoretical Physics. Yet, in such instances, international panels scrupulously examine research programs, and the recipients typically sketch their research plans and request the monies.

Officials also argued that the 7 institutes deserved the monies so that they could ramp up operations in preparation for next year's competition. Yet any such head start makes a mockery of notions of fairness and equity in the awarding of competitive peer-reviewed grants and undermines Canada's international reputation as a nation where science is done as it should be done.

Over the long run, such an approach can only diminish our scientific competitiveness. Originality, innovation, excel\& lence and scientific rigour — the pillars of peer review - will no longer matter. Inevitably, we will erode both the quality of our science and efforts to commercialize our successes.

Our international counterparts must be wondering whether we have lost our collective wits. Are we a country where research funds are allocated on political whim rather than on merit and excellence? More insidiously, will such measures dis- suade the best and the brightest from accepting positions within Canada?

Such an approach also raises the spectre of ongoing, overt political interference in research funding decisions. If bureaucrats and politicians can arbitrarily anoint beneficiaries of research largesse, can they not just as arbitrarily veto others? It is easy to imagine research in politically sensitive areas such as stem cells and abortion being scuttled.

Canada has long sought to skirt such political quagmires by leaving scientific funding decisions in the hands of independent agencies such as the Canadian Institutes of Health Research. Although such agencies are imperfect, as a recent international peer panel recently concluded with regard to the structure, functions and processes of the Canadian Institutes of Health Research, their commitment to peer review is exemplary. The fact is that peer review, albeit labour intensive and somewhat slow, remains the best of all possible options because it attempts to achieve a rational decision through a fair, open and transparent process.

Instead of building on that tradition, measures such as the \$I million in handouts to the 7 institutes usher in a new era of pork-barrel science. Without peer review, it is impossible to justify such outlays, however worthy each institute might be. Rather, the government should have funneled the monies into the Canadian Institutes of Health Research, which received a scant $5 \%$, or $\$ 37$ million, increase to its core $\$ 737$ million budget. As an international benchmark, we spend only $22 \%$ of the per capita amount spent by the US National Institutes of Health on research. Yet, instead of redressing this worrisome gap, Mr. Flaherty's budget opens the gates to scientific mediocrity.

So egregious is the \$105 million allocation to the 7 institutes that we urge all involved parties to beat a quiet, but hasty retreat and instead pump the monies into next year's internationally peer-reviewed competition. If we are to abandon the use of peer review and scientific input in allocating research monies, we must be prepared to live in a world in which research is little more than a component of the political pork barrel, in which researchers must decide whether it is more productive to craft strong scientific proposals that can withstand the scrutiny of peer review or to register as lobbyists and assiduously work the political summer barbecue circuit. Thanks but no thanks, Mr. Flaherty.

\section{Paul C. Hébert}

Editor-in-Chief, $C M A J$

For the CMAJEditorial-Writing Team (Paul C. Hébert, Matthew Stanbrook, Barbara Sibbald, Ken Flegel, Noni MacDonald, Wayne Kondro and Amir Attaran) Ottawa, Ont. 